\title{
News from the Field
}

\section{PATIENT PERCEPTIONS OF ACUPUNCTURE}

A cohort of low-income older adults with multiple comorbidities appreciated having long-term acupuncture treatments as a way to reduce medication use and maintain health, according to a qualitative study in JACM: The Journal of Alternative and Complementary Medicine. The 15 participants recruited from a no-cost acupuncture clinic were dissatisfied with conventional healthcare and trusted the acupuncture clinic to help maintain their health. The participants considered improvements in mood, energy, and well-being important benefits of acupuncture treatments. www.liebertpub.com/doi/10 $.1089 / \mathrm{acm} .2017 .0239$

\section{NEW MASTER'S LEVEL PROGRAM ANNOUNCED}

The Acupuncture \& Integrative Medicine College in Berkeley, CA, announced plans to offer a new revised Master's degree program, which will combine conventional medicine with traditional Eastern medical practices. The Master of Science in Oriental Medicine program aims to educate aspiring acupuncturists who also want to practice Traditional Chinese Medicine. The program has an integrative medicine focus and is designed to be completed in about 3 years. https://www.aimc.edu/

\section{FLORIDA CLINIC OFFERS BATTLEFIELD ACUPUNCTURE}

The Jacksonville Veterans Administration (VA) Outpatient Clinic offers veterans Battlefield Acupuncture (BFA) treatments in an effort to reduce the use of opioid medications. BFA was developed by retired Air Force Col. Richard C. Niemtzow, MD, PhD, MPH-editor-in-chief of Medical Acupuncture - to relieve pain quickly in the field. The treatment involves placing needles in sequence into 5-10 points in the ear. Robert G. Lee, MD, at the Jacksonville VA said that patients experience few side-effects and that the needles activate areas of the brain that decrease pain signals. The treatment is an alternative to opioid pain medications. http:// jacksonville.com/news/military/2018-01-29/jacksonville-vaclinic-offers-battlefield-acupuncture-opioid-alternative

\section{GROUP ACUPUNCTURE FOR PATIENTS WITH FIBROMYALGIA}

Female patients with confirmed fibromyalgia receiving acupuncture in a group setting experienced clinically significant reductions in pain and fatigue at the end of treatment and at a 4-week follow up; women in the control group, who received group education, did not experience these effects. Scott D. Mist, PhD, and Kim Dupree Jones, PhD, both at the Oregon Health \& Science University in Portland, conducted a random allocation study with 30 participants who were suffering from moderate-to-severe pain. Women in the intervention group received 20 manual acupuncture treatments during a 10-week period. The authors reported in Pain Medicine that the women tolerated the acupuncture. https:// academic.oup.com/painmedicine/advance-article-abstract/ doi/10.1093/pm/pnx322/4856005?redirectedFrom=fulltext

\section{WHITE PAPER SUGGESTS ACUPUNCTURE FOR PAIN}

The Pain Task Force of the Academic Consortium for Integrative Medicine and Health-a 72-member North American organization-released "Evidence-based Nonpharmacologic Strategies for Comprehensive Pain Care: The Consortium Pain Task Force White Paper." Acupuncture was among the nondrug modalities discussed. The authors reported that acupuncture could be used to treat postoperative pain and acute nonsurgical pain with few risks. The report also described the use of acupuncture for cancer pain and chronic pain, with the course of treatment chosen based on the term and severity of the problem. The report concluded that acupuncture was costeffective and that the benefits persisted over time. http:// nonpharmpaincare.org

\section{ACUPUNCTURE COULD HELP PATIENTS WITH OVERACTIVE BLADDER}

Yuwei Zhao, MM, at the Guang'anmen Hospital, China Academy of Chinese Medical Sciences, and colleagues, reported in Medicine about a literature review of 10 randomized controlled trials that showed that patients with overactive bladder may benefit from electroacupuncture 
(EA) treatments. The EA treatments reduced 24-hour nocturia episodes and could reduce the number of voiding and incontinence episodes. Only a few of the participants reported experiencing adverse events from the treatments. The researchers noted that additional research is needed. https://journals.lww .com/md-journal/Fulltext/2018/02230/Acupuncture_for_ adults_with_overactive_bladder__A.31.aspx

\section{NEW JERSEY LEGISLATURE CONSIDERS DRY NEEDLING BILL}

New Jersey State Senators Nellie Pou (D-NJ) and Richard Codey (D-NJ) have prefiled a bill for consideration in the 2018 NJ State Legislature. If passed, the legislation (SB 431) would permit certain physical therapists to perform dry needling. In 2017, NJ officials decided that the technique was not within a physical therapist's scope of practice, based on the legal opinion of the state attorney general at the time. The new bill states:

\footnotetext{
"Dry needling" means a physical intervention that uses a dry, filiform needle, without medication or other deliverable, to penetrate the skin and stimulate underlying muscular tissue, connective tissues, or myofascial trigger points for the management of neuromusculoskeletal pain and movement impairments. "Dry needling" shall not mean the stimulation of auricular or distal points or the practice of acupuncture.
}

Physical therapists would be required to take training in dry needling and have 2 years of experience. www.njleg .state.nj.us/2018/Bills/S0500/431_I1.PDF

\section{EXPERTS DEBATE ACUPUNCTURE FOR CHRONIC PAIN}

Mike Cummings, $\mathrm{MB}, \mathrm{ChB}$, medical director of the British Medical Acupuncture Society, argues in The BMJ that acupuncture is a safe alternative to drugs for chronic pain, while professors Asbjørn Hróbjartsson, MD, PhD, MPhil, at the University of Southern Denmark, and Edzard Ernst, MD, PhD, at the University of Exeter, say that doctors should not recommend acupuncture for pain due to the lack of evidence that acupuncture is clinically beneficial. The article includes a podcast featuring background information on the topic and interviews with the authors. www.bmj.com/content/360/bmj.k970

\section{CLINICAL TRIAL ON ACUPUNCTURE FOR CHILDREN'S HEADACHES}

Dorte Melgaard, PhD, at Vendsyssel Hospital, in Hjørring, Denmark, is recruiting 204 children, ages 9-17, who have been diagnosed with headache by a pediatrician, and who have had 8 or more headaches in the month prior to study entry, for a controlled study on the effect of acupunc- ture as a treatment for headache in children. The children will be randomized for training or for training and acupuncture. The study is expected to be completed in December 2020. https://clinicaltrials.gov/ct2/show/NCT03426800?term= acupuncture $\&$ recrs $=$ abd $\&$ rank $=45$

\section{ACUPUNCTURE ORGANIZATION PROVIDES RELIEF TO PUERTO RICANS}

Acupuncturists Without Borders provided free community acupuncture treatments, in Springfield, MA, to Puerto Rican evacuees after Hurricane Maria in Puerto Rico. The organization teamed up with the Springfield Family Resource Center of Gandara, which has served 400 families who evacuated from the island. The clinic is open 2 days per month and provides acupuncture in a group setting to relieve stress. Acupuncturists Nancy Edwards, LAc, MAc, and Dedie King, MEd, MAc, LicAc, members of Acupuncturists Without Borders, provide the treatments. http://valleyadvocate .com/2018/02/22/puerto-rican-evacuees-receive-trauma-reliefacupuncture-springfield/

\section{EXPERT SPOTLIGHT}

Laura Bowman, MD, DABMA, and David Miller, MD, LAc, are the cochairs, and Freda Dreher, MD, FAAMA, is the vice-chair, of the American Academy of Medical Acupuncture's 30th annual Medical Acupuncture Symposium, April 13-15, 2018, in Kansas City, MO, The theme is "Across Time and Continents-the Integration of Ancient and Modern in 21st Century Acupuncture."

Benjamin Kligler, MD, MPH, national director of the Integrative Health Coordinating Center at the Office of Patient-Centered Care \& Cultural Transformation at the Veterans Health Administration, will be the guest editor of a special issue of Medical Acupuncture focusing on the use of acupuncture in the Veterans Health Administration.

Richard C. Niemtzow, MD, PhD, MPH, the Consultant for the Air Force Surgeon General for Integrative Medicine, the creator of Battlefield Acupuncture, and the Editor-in-Chief of Medical Acupuncture, was mentioned in an article in Military Medicine, about his efforts to collaborate with the Chinese People's Liberation Army physicians. The article was "Building Relationships and Trust One Needle at a Time: A Recipe for Success for the International Health Specialist (IHS)," by Will Chu, published January 1, 2018, Volume 183(1-2):1-2.

Wang Shuxia, LAc, PhD, a licensed acupuncturist registered in China's Ministry of Health, founded a new Traditional Chinese Medicine cancer rehabilitation center at the Texas Medical Center in Houston. 